\title{
Greenhouse Gas Emissions and Cost Analyses for the Treatment Options of Food Waste and Human Excrement
}

\author{
Sora Yi ${ }^{*}$, Kee-Young Yoo ${ }^{2}$ \\ ${ }^{1}$ Department of Urban Planning Research, Daejeon Development Institute, Daejeon, Korea \\ ${ }^{2}$ Department of Safe and Environment Research, Seoul Institute, Seoul, Korea \\ Email: *sora@djdi.re.kr
}

Received 25 March 2014; revised 23 April 2014; accepted 17 May 2014

Copyright (C) 2014 by authors and Scientific Research Publishing Inc.

This work is licensed under the Creative Commons Attribution International License (CC BY). http://creativecommons.org/licenses/by/4.0/

(c) (7) Open Access

\begin{abstract}
This study suggested environmental and economic evaluations by developing a scenario according to the various treatment options of food waste in Korea. In particular, the study evaluated the possibility about the combined treatment of food waste and human excrement after using food waste disposers (FWDs). The scenario including only composting (133 $\mathrm{kg} \mathrm{CO}_{2}$ equiv./ton-household organic waste) or only FWDs (125 $\mathrm{kg} \mathrm{CO}_{2}$ equiv./ton-household organic waste) was superior to the other scenarios in the environmental aspect and the scenario including only composting (101 USD/ton-household organic waste) was superior to the other scenarios in the economic aspect. However, the study discovered that $52 \%$ of greenhouse gas emission was reduced when sewage pretreatment was conducted in houses after using FWDs and also when biogas was collected on site and utilized in the private power station. Furthermore, the energy saving effect due to recovery of biogas has found to be larger in the environment aspect than in the economic aspect.
\end{abstract}

\section{Keywords}

Food Waste Disposer, Food Waste Drying Machine, Composting, Biogasification, Automatic Vacuum Waste Collection System

\section{Introduction}

Food waste and human excrement, i.e., human biological waste is household organic waste which is highly valued as the production of biomass such as biosolids, biogasification, and bioethanol [1]-[4]. In Korea, 97.1\% of

*Corresponding author.

How to cite this paper: Yi, S. and Yoo, K.-Y. (2014) Greenhouse Gas Emissions and Cost Analyses for the Treatment Options of Food Waste and Human Excrement. Journal of Environmental Protection, 5, 597-607.

http://dx.doi.org/10.4236/jep.2014.57061 
the total food waste generation has been separately collected food waste from municipal solid waste (MSW) and recycled to animal feed and compost since 2005 [5]. Due to food waste separation from MSW, MSW composition in landfill sites and incineration plants has been changed. As a result, the efficiency of waste to energy in landfill sites and incineration plants was differed by changing of biodegradable composition and lower heating value (LHV), respectively. The existing study has reported that the LHV of municipal solid waste increases by $6.4 \%$ when $32.8 \%$ of the household food waste used the food waste disposers (FWDs). In that report, the ratio of household combustible waste of the total combustible waste was $58.6 \%$, the ratio of household food waste of the household combustible waste was $44.0 \%$ [6].

Since food waste was collected separately from the municipal solid waste, unsanitary problems, including unpleasant odors, germs, insects, and feeling of aversion from curbside waste, have increased. Due to these problems, many households tend to install food waste disposal units (FWDs or food waste decomposers by using drying system) such that food waste can be treated before it is taken out [7]. Recently, FWDs are supplied to large scale apartment complexes via the built-in system in general. However, the applicability of these units is not high due to the burden of additional electricity and water demands as well as the early purchase cost [8].

Figure 1 shows sewer systems in Seoul, Korea. The FWDs give effects for wastewater loadings and biogas production in the public wastewater treatment plants (WWTPs) [9]-[11].

Seoul has already carried out pilot studies in order to treat food waste in the public WWTPs. The studies were conducted by introducing domestic in-sink FWDs to 447 households in apartment houses with the sewage pretreatment facilities and 538 households in apartment houses with the sewage pretreatment facilities combined with human excrement. The result of the pilot studies has found that the combined treatment of food waste with human excrement lowers the effluent biological oxidation demand (BOD) concentration (food waste: 1055.1 $\mathrm{mg} / \mathrm{L}$, food waste and human excrement mixture: $804.1 \mathrm{mg} / \mathrm{L}$ ), and increases SS concentration (respectively, $905.7 \mathrm{mg} / \mathrm{L}, 1564.4 \mathrm{mg} / \mathrm{L}$ ) and n-Hexane concentration (respectively, $195.9 \mathrm{mg} / \mathrm{L}, 240.5 \mathrm{mg} / \mathrm{L}$ ), more than the food waste treatment [12] [13]. If it is considered that the separate sewer system for the separated treatment of human excrement covers $14 \%$ of the sewer service area in Seoul, it needs to introduce this combined treatment of food waste with human excrement in order to reduce the environmental burden as well as to promote the convenience of the citizens.

Meanwhile, food waste has shown various environmental and economic evaluation results according to the treatment methods [14] [15]. In particular, the waste has been evaluated such that the benefit/cost (B/C) was 0.85 when domestic in-sink FWDs were used, $\mathrm{B} / \mathrm{C}$ was 0.19 when the food waste was separated and put out for collection, $\mathrm{B} / \mathrm{C}$ was 0.39 when the food waste was separated and put out for collection after using the food waste drying machines (FWDMs), and B/C was 0.18 when the automatic vacuum waste collection (AVWC) system was utilized [16].

Therefore, this study suggested environmental and economic evaluations about the various treatment methods of food waste and the combined treatment of food waste with human excrement after installing domestic in-sink FWDs. The environmental evaluation indicated as greenhouse gas (GHG) emissions by methane gas production and the energy equivalent and net energy consumption, which is required in the treatment. The economic

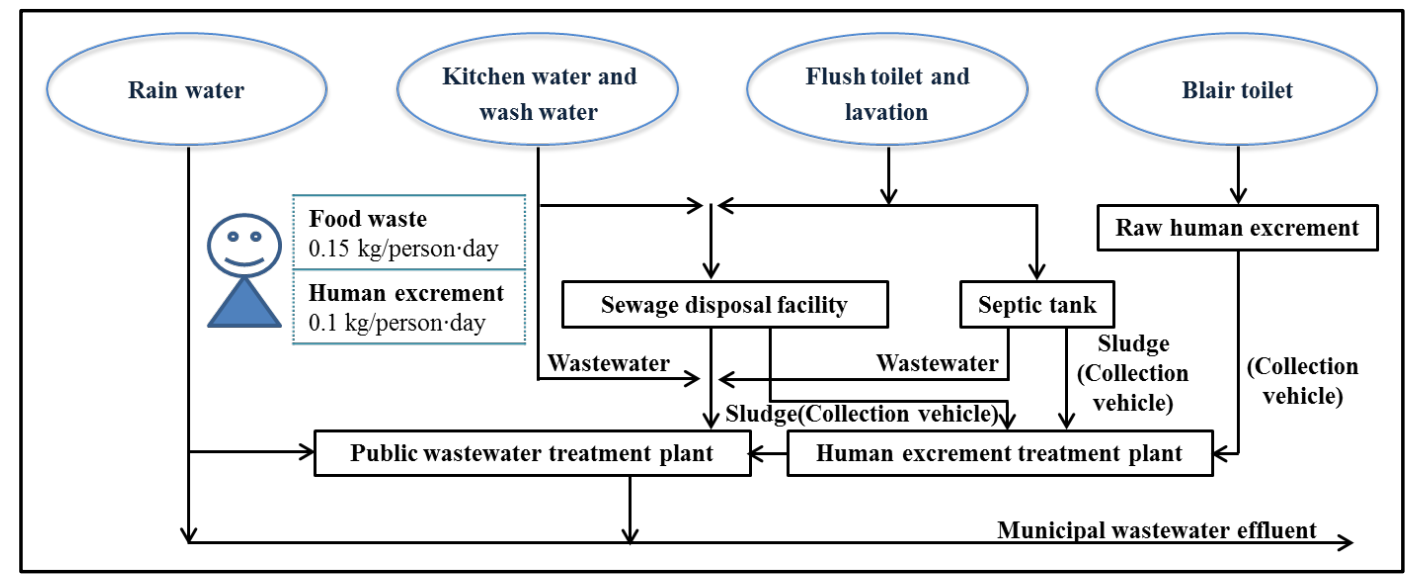

Figure 1. Sewer systems in Seoul. 
evaluation is indicated as construction and operation costs, which are required in the treatment. Further, the additional social cost considering the value of domestic labor of separating and handling food waste.

\section{Materials and Methods}

\subsection{Functional Unit and Scope}

This study analyzed the properties of food waste and human excrement and the characteristics of the handling process and treatment of the household organic waste; scenarios which reflected the characteristics were developed. The functional unit is a measure of the function of the studied system and it provides a reference to which the inputs and outputs can be related. In this study, the functional unit of food waste was set to 1 ton of food waste from 6667 persons, which was based on $0.15 \mathrm{~kg} / \mathrm{person} \cdot$ day, in order to calculate the parameter. Further, the functional unit of human excrement was set to 0.6667 ton (= 0.7 ton in the text below) from 6667 persons, because one human produces $0.1 \mathrm{~kg}$ of human excrement per day.

To evaluate GHG emissions and cost for the treatment options of food waste and human excrement mixture, the functional units set the quantity of human excrement per population (6667 persons) that handles 1 ton of food waste. Therefore, the functional unit for calculating parameters is 1.7 tons of household organic waste, which is the total amount of about 1 ton of food waste and 0.7 ton of human excrement. It is necessary in order to compare the scenarios of 1 ton of food waste and 0.7 ton of human excrement, which are transferred and treated in the different processes, with the scenarios of 1.7 tons of food waste and human excrement mixture, which are combined and treated in one system. The parameters based on 1 ton of food waste were calculated in order to reflect the social cost of separating and putting out the food waste for collection.

Net energy consumption (= Energy consumption in process minus energy recovery in process) was reflected in energy use. The GHG evaluation calculated the emissions from each process as well as the saved effect due to the recovery of biogas (the alternative effect based on the Korean power plants using LNG). The economic evaluation calculated the costs per each process and the saved effect due to the recovery of biogas.

As it was assumed that public sewer is the combined system and human excrement is treated in a separate sanitary treatment plant by collecting from the septic tanks, most of the scenarios did not include the use of energy, GHG emissions, and the costs according to the public wastewater treatment on human excrement. For the scenarios including the combined treatment, treated wastewater is flowed into public WWTPs; however, the part of public WWTPs of human excrement was ignored, according to the mass balance which had been applied before.

\subsection{Properties and Characteristics of Household Organic Waste}

\subsubsection{Characteristics of Food Waste}

There are big differences in the amount of food waste generation change to according to the building types or sources. Generally, the amount of generation from residential and commercial (restaurants) sectors is 0.33 $\mathrm{kg} /$ person/day [17], but it range from 0.12 to $0.25 / \mathrm{kg} /$ person/day according to the types of houses [13] [17] [18]. There are also differences in the properties of food waste according to the areas and the seasons, yet, fruits and vegetables represent the highest share of them, $55 \%$ to $75 \%$ (Table 1 ).

Food waste is treated by dividing it into public and private facilities. In the public facilities, the following occurs: animal feed (26.1\%), composing (65.4\%), and others (biogasification) (8.5\%). Animal feed are of great importance in the private facilities because they make up more than half of total amount: animal feed $58.8 \%$, composing $38.2 \%$, and others $3.2 \%$.

The result from the survey of this research reveals that $20.7 \%$ of total respondents in Seoul are now using food waste disposal units: FWDMs (9.1\%); compost bins (8.0\%); FWDs (2.1\%); and others (1.5\%). Further, $62.2 \%$ of total respondents plan to use them: FWDMs (26.0\%); FWDs (24.3\%); compost bins (6.8\%); and others $(0.4 \%)$ in the future.

\subsubsection{Characteristics of Human Excrement}

Human excrement is generated in blair and flush toilets in Korea. The excrement in blair toilets is referred to as raw human excrement; the one from the flush toilet is processed through the septic tank sludge. Men expel urine and feces seven times throughout the day, including one time of feces and six times of urine per day. Human excrement, when calculated, is $1 \mathrm{~L} /$ person/day; feces account for $0.1 \mathrm{~L} /$ person/day. BOD of expelled human excrement is more than $20000 \mathrm{mg} / \mathrm{L}$ and SS is $27,500 \mathrm{mg} / \mathrm{L}$ [19]. 
Table 1. Properties of food waste in Korea.

\begin{tabular}{|c|c|c|c|c|c|c|}
\hline \multirow{2}{*}{$\begin{array}{c}\text { Composition } \\
\text { (\%) }\end{array}$} & \multicolumn{2}{|c|}{ Korea } & \multicolumn{4}{|c|}{ Seoul } \\
\hline & Total & Residential & & & Apa & ouses \\
\hline Total & 100 & 100 & & & & \\
\hline Cereals & 19.5 & 19.5 & & & & \\
\hline $\begin{array}{c}\text { Vegetables } \\
\text { Fruits }\end{array}$ & 55.5 & 60.5 & $\begin{array}{l}49.3 \\
25.7\end{array}$ & 75.0 & $\begin{array}{l}44.8 \\
20.9\end{array}$ & 65.7 \\
\hline Fish meats & 6.6 & 4.4 & & & & \\
\hline Others & 18.5 & 15.6 & & & & \\
\hline
\end{tabular}

As shown in Table 2, BOD of septic tank sludge, which is carried into the Seoul human excrement treatment facilities, is higher than that of the US, as 8674 to $11343 \mathrm{mg} / \mathrm{L}$ [20] [21].

\subsection{Scenario Development}

A total of six scenarios were suggested by applying the applicable conditions that were most practical in Seoul City; the contents of the concrete scenarios are shown in Table 3. Composting was selected, except for animal feed, in the current food waste treatment methods because Korea is similar to a traditional agrarian country and thus, it can secure more stable facilities and supply and demand chain than the ones for animal feed.

This study included the options to install FWDMs or FWDs in individual houses because there were intentions to purchase FWDMs or FWDs in the previous survey. The AVWC systems, which have been recently distributed to housing complexes, were added in the transport option.

In the developed scenarios, household organic waste is divided into food waste, human excrement, and food waste and human excrement mixture (Table 4). Energy (electric power and diesel) and material (public tap water) are consumed in each transfer and treatment processes, GHG is emitted accordingly, and costs are required. Scenario 6 also evaluated the reduction level of GHG by recovering biogas. If food waste is put out after it has been dried in a FWDM, energy, which is necessary for the use of elevators in apartments, for the collection and transport, and for the transport of the waste to aerobic compositing facilities, will be reduced. If food waste is sent to the public WWTPs after sewage pretreatment in houses, energy for public WWTPs operation will be significantly reduced.

\subsection{Key Factors Analysis}

\subsubsection{Possibility of a Combined Treatment of Household Organic Waste}

This study evaluated the characteristics of anaerobic digestion and biogas generation on mixed liquids of grinded food waste and human excrement mixture by the biochemical methane production (BMP) test.

The characteristics of the used samples are shown in Table 5 and the reaction formula to generate methane, which was calculated based on the measured data, was Equation (1).

$$
\mathrm{C}_{4.23} \mathrm{H}_{6.84} \mathrm{O}_{0.58}+2.23 \mathrm{H}_{2} \mathrm{O} \rightarrow 1.41 \mathrm{CO}_{2}+2.83 \mathrm{CH}_{4}
$$

The ingredient content in gas, which was calculated based on this formula, was $66.7 \%$ of $\mathrm{CH}_{4}$ and $33.3 \%$ of $\mathrm{CO}_{2}$. The early ingredient content of gas in headspace, which was corrected by considering the solubility of gas ingredients, was $84 \%$ of $\mathrm{CH}_{4}$ and $16 \%$ of $\mathrm{CO}_{2}$. The amount of accumulated methane generation was largest when grinded food waste was $94 \mathrm{~mL}$, and non-thickened human excrement with flush water was $51 \mathrm{~mL}$. The amount of methane generation based on inflow of $\mathrm{COD}_{\mathrm{Cr}}$ for grinded food waste and for non-thickened human excrement with flush water was $0.342 \mathrm{~L} \mathrm{CH}_{4} / \mathrm{g}$ COD and $0.423 \mathrm{~L} \mathrm{CH}_{4} / \mathrm{g} \mathrm{COD}$, respectively.

The existing study showed the range of 0.333 to $0.347 \mathrm{~L} / \mathrm{g} \mathrm{COD}_{\mathrm{Cr}}$ [22] on the methane gas generation of mixed samples. Methane gas generation, which was collected after the mixed samples were digested for 20 days, was $0.35 \mathrm{~L} / \mathrm{g} \mathrm{COD}_{\mathrm{Cr}}$ per person, thus, the amount of methane gas generation was $24.85 \mathrm{~L} /$ person/day for 71 g/day (food waste $35 \mathrm{~g}+$ human excrement $36 \mathrm{~g}$ ) [23]. 
Table 2. Properties of septic tank sludge and raw human excrement.

\begin{tabular}{|c|c|c|c|c|c|c|c|c|}
\hline \multicolumn{2}{|c|}{ Location } & Type & BOD (mg/L) & COD (mg/L) & TS (mg/L) & $V^{*}(\%)$ & TN (mg/L) & TP (mg/L) \\
\hline \multirow{2}{*}{\multicolumn{2}{|c|}{ Jungnang }} & Septic tank sludge & 11343 & 9812 & 19761 & 85.9 & 1510 & 175 \\
\hline & & Raw human excrement & 13638 & 12044 & 34178 & 76.4 & 2655 & 298 \\
\hline \multirow{6}{*}{ Korea } & \multirow{2}{*}{ Seonam } & Septic tank sludge & 7209 & 3236 & 6558 & - & - & - \\
\hline & & Raw human excrement & - & - & - & - & - & - \\
\hline & \multirow{2}{*}{ Nanji } & Septic tank sludge & 8674 & - & 8000 & - & - & - \\
\hline & & Raw human excrement & 16059 & - & 19000 & - & - & - \\
\hline & \multirow{2}{*}{ US } & Septic tank sludge & 6480 & - & 12862 & 70.2 & 588 & 210 \\
\hline & & Raw human excrement & - & - & - & - & - & - \\
\hline
\end{tabular}

*Based on TS.

Table 3. Characteristics of the developed scenarios.

\begin{tabular}{|c|c|c|c|c|}
\hline Scenarios & Food waste disposal units & Food waste collection & Food waste treatment & Human excrement treatment \\
\hline Scenario 1 & - & Curbside & Composting & Septic tank in houses \\
\hline Scenario 2 & - & AVWC system & Composting & Septic tank in houses \\
\hline Scenario 3 & FWDMs in individual houses & Curbside & Compositing & Septic tank in houses \\
\hline Scenario 4 & FWDs in individual houses & \multicolumn{2}{|c|}{ Discharge the grinded food waste to the public WWTPs } & Septic tank in houses \\
\hline Scenario 5 & FWDs in individual houses & \multicolumn{2}{|c|}{$\begin{array}{c}\text { Pretreatment in apartments and discharge the sewage to } \\
\text { the public WWTPs }\end{array}$} & Septic tank in houses \\
\hline Scenario 6 & FWDs in individual houses & \multicolumn{3}{|c|}{$\begin{array}{l}\text { Combined biogasification of food waste and human excrement in apartments } \\
\text { and discharge the sewage to the public WWTPs }\end{array}$} \\
\hline
\end{tabular}

Table 4. Energy and material consumption, GHG emissions, and recovery in various scenarios.

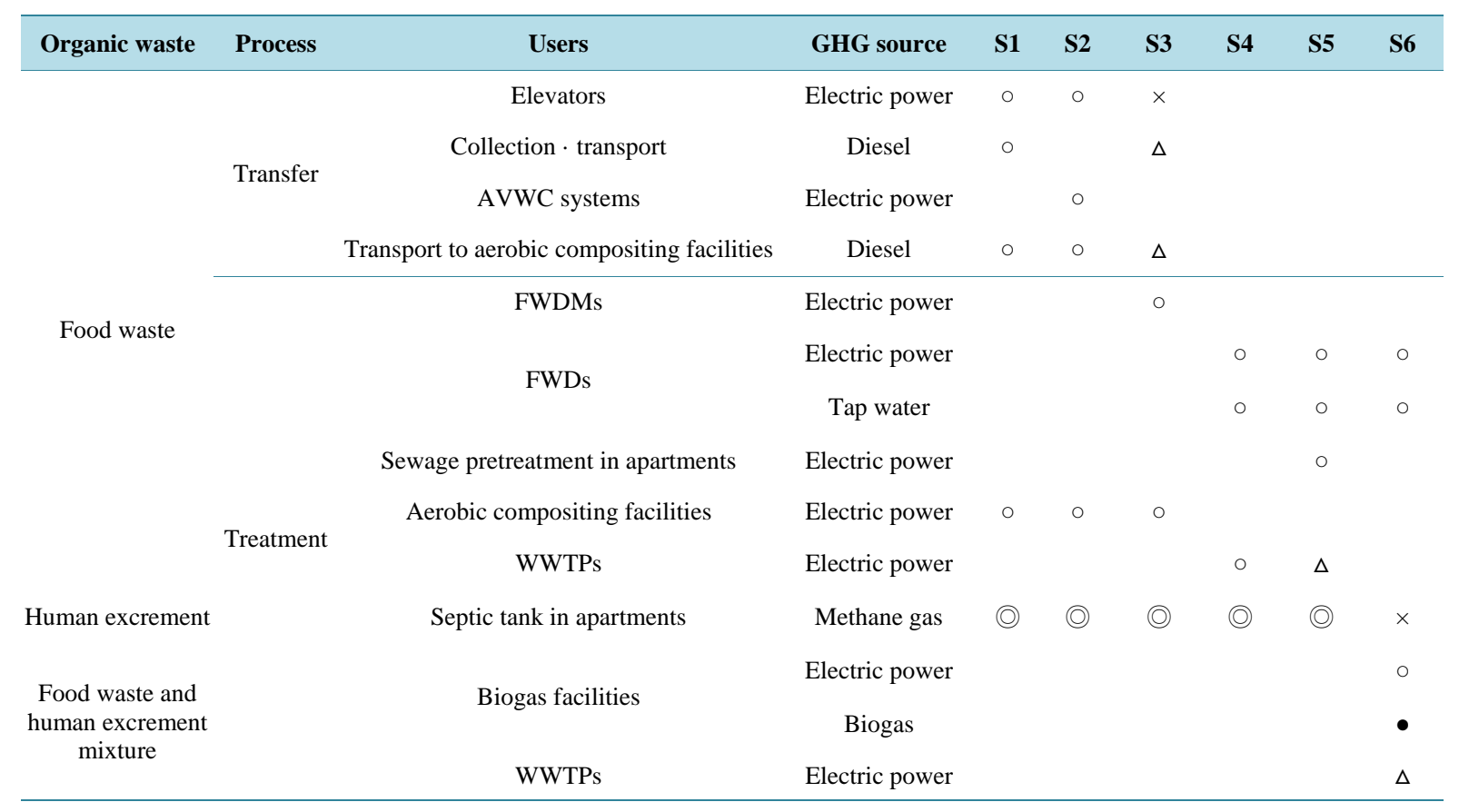

$\circ$ : Consumption in full operation, (): Emissions in full operation, $\Delta$ : Consumption in half or less operation, $\times$ : Insignificant consumption/emissions, and $\bullet$ : Recovery in full operation. ${ }^{*}$ S1, S2, S3, S4, S5, and S6 stand for scenarios 1 - 6, respectively. 
Meanwhile, the amount of $\mathrm{CH}_{4}$ generation per person in a septic tank was calculated as $0.423 \mathrm{~L} \mathrm{CH}_{4} / \mathrm{g} \mathrm{COD}_{\mathrm{Cr}}$ $\times 1 / 2.4\left(\mathrm{~g} \mathrm{COD}_{\mathrm{Cr}} / \mathrm{g}\right.$ TS) [24] $\times 27$ (TS, cases of toilets in US) [25] $\times 70 \%$ (storage solid material) [24] $\times 0.12$ (room temperature) $/ 0.27$ (temperature range of $37^{\circ} \mathrm{C}-41^{\circ} \mathrm{C}$ ) [26] $=1.481 \mathrm{~L} \mathrm{CH}_{4} /$ person/day; the weight was $1.481 \mathrm{~L} \times 16 \mathrm{~g} / 22.4 \mathrm{~L}=1.058 \mathrm{~g} /$ person/day.

\subsubsection{Parameters in Process Units}

Parameters were calculated by dividing them largely into transfer and treatment processes in Table 6, Table 7, and Table 8. The parameters were calculated as consumption, emission, and recovery by GHC source (electric

Table 5. BMP test of food waste and human excrement.

\begin{tabular}{|c|c|c|c|c|c|c|}
\hline Item (unit) & pH & $\mathrm{COD}_{\mathrm{Cr}}(\mathrm{mg} / \mathrm{L})$ & $\mathrm{COD}_{\mathrm{Mn}}(\mathrm{mg} / \mathrm{L})$ & TN (mg/L) & $\mathrm{NH}_{3}-\mathrm{N}(\mathrm{mg} / \mathrm{L})$ & TP (mg/L) \\
\hline Food waste & 4.46 & 136,887 & 26,000 & 6179 & 2748 & 2043 \\
\hline Human excrement with flush water & 7.79 & 2388 & 645.8 & 111.5 & 95.3 & 19.38 \\
\hline Thickened human excrement & 7.81 & 8150 & 2625.5 & 770.2 & 631.5 & 132.4 \\
\hline Item (unit) & TS (mg/L) & VS (mg/L) & VS/TS (\%) & TSS (mg/L) & VSS (mg/L) & VSS/TSS (\%) \\
\hline Food waste & 94,303 & 90,373 & 95.83 & 50,601 & 46,358 & 91.60 \\
\hline Human excrement with flush water & 1800 & 800 & 44.44 & 1130 & 944.4 & 83.56 \\
\hline Thickened human excrement & 20,649 & 12,200 & 59.08 & 6893 & 5597 & 81.20 \\
\hline
\end{tabular}

Table 6. Parameters for transfer processes.

\section{Parameter estimation}

\section{Electric power of the elevator}

- Conditions of the elevator: 20 story apartment, 40 households, height between floors: $2.8 \mathrm{~m}$, the speed of the elevator $90 \mathrm{~m} / \mathrm{min}$, the rated electric power of the elevator $8.3 \mathrm{~kW}$ [27].

- Frequency to put out food waste per household for collection: 10 times per month (20 times for round trip).

- The amount to put out food waste per month: 0.63 ton( $=0.0045$ ton/household/month $\times 3.5 \mathrm{p} /$ household $\times 40$ households).

- Running distance per month of the elevator: $22400 \mathrm{~m}$ ( $=40$ households $\times 20$ times $\times 2.8 \mathrm{~m} \times 20$ floors $\div 2$ ).

- Used electricity power per month of the elevator: $34.4 \mathrm{kWh}(=8.3 \mathrm{~kW} \times 22400 \mathrm{~m} \div 90 \mathrm{~m} / \mathrm{min} \div 60 \mathrm{~min} / \mathrm{hr})$.

- Used electricity energy per ton of food waste: $54.6 \mathrm{kWh}(=34.4 \mathrm{kWh} \div 0.63 \mathrm{ton})$.

- Electric charges per ton of food waste: 3 USD $(=34.4 \mathrm{kWh} \times 0.0551 \mathrm{USD} / \mathrm{kWh} \div 0.63 \mathrm{ton})$.

- Electric power for elevator is excluded when FWDMs are used.

Diesel for collection and transport

- Vehicle conditions: load capacity: 5 tons, transportation distance per day: $37 \mathrm{~km}$, the frequency of collection per day: 3 times, collection amount per day: 15 tons-food waste, fuel efficiency: $3.2 \mathrm{~km} / \mathrm{L}-$ Diesel.

- Consumption of diesel for collection and transport per ton of food waste: $0.8 \mathrm{~L} / \mathrm{ton}(=37 \mathrm{~km} \div 3.2 \mathrm{~km} / \mathrm{L} \div 15$ ton)

Transfer - Cost for collection and transport per ton of food waste: 55.6 USD/ton [28].

- The consumption and the cost of diesel for dried food waste were estimated as $18 \%$ of total food waste for FWDMs [29].

\section{Electric power of an AVWC system}

- Conditions of the facilities: The construction cost: 17 million USD, the repair and maintenance cost: 6.8 million USD, the persisting period: 20 years, the amount of waste from an AVWC system for 20 years: 41449 tons.

- Used electricity energy per ton of food waste: $324.3 \mathrm{kWh}(=200 \mathrm{~kW} / \mathrm{hr} \times 3360 \mathrm{hr} \div 2072.5$ tons $)$.

- Construction cost per ton of food waste: 574 USD (= 23.8 million USD $\div 41449$ ton/20 yrs).

- Operating cost per ton of food waste: $186 \mathrm{USD} / \mathrm{ton}[30]$.

\section{Diesel for transport of the compositing facilities}

- Vehicle conditions: load capacity: 5 tons, total transportation distance: $80 \mathrm{~km}$, frequency of transport: 2 times, transportation amount: 10 tons, fuel efficiency: $4.8 \mathrm{~km} / \mathrm{L}-$ Diesel, one driver per vehicle.

- Consumption of diesel per day of a vehicle: $3.3 \mathrm{~L}(=160 \mathrm{~km} \div 4.8 \mathrm{~km} / \mathrm{L} \div 10 \mathrm{ton})$.

- Energy consumption per ton of food waste: $34.7 \mathrm{kWh}(=3.3 \mathrm{~L} \times 9050 \mathrm{kcal} / \mathrm{L} \div 860 \mathrm{kWh} / \mathrm{kcal})$.

- Transport cost per ton of food waste: 30 USD [31].

The consumption and the cost of diesel for dried food waste were estimated as 18\% of total food wastefor FWDMs [29]. 


\section{Parameter estimation}

Electric power of the FWDM [29]

- Energy consumption of the FWDM per ton of food waste: $3481 \mathrm{kWh}(=55 \mathrm{kWh} /$ household/month $\div 0.0158$ ton/month/household).

- Cost to purchase the FWDM per ton of food waste: 154 USD/ton (= 295 USD/10 years $\div 1.92$ ton/10 years).

- The electric charges of the FWDM per ton of food waste: $192 \mathrm{USD} / \mathrm{ton}(=3481 \mathrm{kWh} \times 0.0551 \mathrm{USD} / \mathrm{kWh})$.

\section{Electric power of the FWD [29]}

- Energy consumption of the FWD per ton of food waste: $95 \mathrm{kWh}(=1.5 \mathrm{kWh} /$ household/month $\div 0.0158$ ton/household/month).

- Cost to purchase the FWD per ton of food waste: 380 USD (= 730 USD/10 years $\div 1.92$ ton/10 years).

- The electric charges of the FWD per ton of food waste: 5.2 USD (= $95 \mathrm{kWh} \times 0.0551 \mathrm{USD} / \mathrm{kWh}$ ).

Water use of the FWD [13]

- Water consumption of the FWD per ton of food waste: $27 \mathrm{~m}^{3}(=0.12 \mathrm{~m} / \mathrm{month} / \mathrm{p} \times 3.5 \mathrm{p} /$ household $\div 0.0158$ ton/household /month).

- Rate of water for the FWD per ton of food waste: $8.6 \mathrm{USD}\left(=27 \mathrm{~m}^{3} \times 0.32 \mathrm{USD} / \mathrm{m}^{3}\right)$.

Electric power of pretreatment facilities [29]

- Conditions of the facilities: For the quality standards of discharge water, BOD is less than $100 \mathrm{mg} / \mathrm{L}$, SS is less than $300 \mathrm{mg} / \mathrm{L}$, n-Hexane is less than $300 \mathrm{mg} / \mathrm{L}$. The treatment capacity is 400 households and the quantity of discharge water per day is $49 \mathrm{~m}^{3}$. The construction cost is 206 thousand USD (erection of frameworks is 86 thousand USD, the equipment work is 120 thousand USD, this is just used for treatment of food waste by using the combined treatment plant of food waste and human excrement). The persisting period is 10 years and the annual quantity to treat food waste is 0.192 tons.

- Energy consumption of the pretreatment: $688 \mathrm{kWh}(=4350 \mathrm{kWh} /$ month $\div 400$ household $\div 0.0158$ ton/household /month).

Treatment - Construction cost per ton of food waste: 268 USD (= 206 thousand USD $\div 400$ household $\div 1.92$ ton/household/10 years).

- Electricity cost per ton of food waste: $38 \mathrm{USD}(=688 \mathrm{kWh} \times 0.0551 \mathrm{USD} / \mathrm{kWh})$.

- Maintenance cost per ton of food waste: 47 USD ( $=300$ USD/month $\div 400$ household $\div 0.0158$ ton/household/month).

Electric power of the aerobic compositing facilities

- $\quad$ Electric energy consumption per ton of food waste: $111.7 \mathrm{kWh}$ [29].

- Treatment cost per ton of food waste: 80 USD [18].

\section{Electric power of the public WWTP [29]}

- $\quad$ Energy consumption per ton of food waste (sludge treatment, supply of air): $10.3 \mathrm{kWh}$.

- Cost per ton of food waste (sludge treatment, supply of air): 15 USD.

- $1 \mathrm{kWh} /$ ton-food waste was applied in treatment (supply of air only in the inflow part) of the pretreatment facilities.

- $1.5 \mathrm{USD} / \mathrm{ton}$-food waste was applied in treatment (supply of air only in the inflow part) of the pretreatment facilities.

- $1.5 \mathrm{USD} /$ ton-food waste was applied in treatment (supply of air only in the inflow part, the inflow part of human excrement was ignored) of the biogas facilities.

\section{Generation of methane gas in a septic tank}

- The conditions of calculation: The amount of human excrement per person per day: $100 \mathrm{~g}$, The amount of human excrement per population (6667 persons, equivalent of 1 ton of food waste generation): 0.6667 ton (= 0.7 ton).

- Generation of methane gas per population (6667 persons): $7.054 \mathrm{~kg}$ (= $1.058 \mathrm{~g} /$ person/day $\times 6667$ person/ton-food waste $\div 1000 \mathrm{~g} / \mathrm{ton}$ ).

- The emissions of methane gas to the air was ignored by forcibly collecting methane gas when 1 ton of food waste and 0.7 ton of human excrement (= mixture 1.7 tons) were combined and treated. 


\section{Continued}

Electric power of the biogasification facilities (Food waste and human excrement mixture)

- Conditions of the facilities: For the quality standards of discharge water, BOD is less than $100 \mathrm{mg} / \mathrm{L}$, SS is less than $300 \mathrm{mg} / \mathrm{L}$, n-Hexane is less than $300 \mathrm{mg} / \mathrm{L}$. The treatment capacity is 400 households and the quantity of discharge water per day is $49 \mathrm{~m}^{3}$. The construction cost is 206 thousand USD (erection of frameworks is 86 thousand USD, the equipment work is 120 thousand USD, this is just used for treatment of food waste by using the combined treatment plant of food waste and human excrement). The persisting period is 10 years and the annual quantity to treat food waste is 0.192 tons.

- Energy consumption of the biogasification per 1.7 tons of food waste and human excrement mixture: $1147 \mathrm{kWh}$ (= $688 \mathrm{kWh} \times 1.6667$ ton-mixed waste) .

- Biogas to electric power per 1.7 tons of food waste and human excrement mixture: $502 \mathrm{kWh}\left(=168 \mathrm{Nm}^{3}\right.$ $\left.\times 9.953 \mathrm{kWh} / \mathrm{Nm}^{3} \times 0.3 \%\right)$.

Treatment

- Construction cost per 1.7 tons of food waste and human excrement mixture: 447 USD (= 268 USD $\times 1.6667$ ton-mixed waste).

- $\quad$ Electricity cost per 1.7 tons of food waste and human excrement mixture: 63 USD (= 38 USD $\times 1.6667$ ton-mixed waste).

- $\quad$ Maintenance per 1.7 tons of food waste and human excrement mixture: 79 USD (= 47.4 USD $\times 1.6667$ ton-mixed waste).

- $\quad$ Saving cost by biogas to electric power on site: 28 USD (= $502 \mathrm{kWh} \times 0.0551 \mathrm{USD} / \mathrm{kWh}$ ).

GHG avoided effect(LNG saving effect) due to utilization of biogas

- Conditions of calculation: $50.8 \mathrm{~kg}$ of $\mathrm{CO}_{2}$ equiv. is generated when LNG, which is applicable to the caloric value, $1 \mathrm{MJ}$ is produced.

- Collection calorie per 1.7 tons of mixture: $6.02 \mathrm{MJ}\left(=168 \mathrm{Nm}^{3} \times 8560 \mathrm{kcal} / \mathrm{Nm}^{3}\right.$ methane $\left.\times 4.1865 \times 10^{-6} \mathrm{MJ}\right)$.

Table 8. Parameters for the social costs and conversion factors.

\section{Parameter estimation}

The value of domestic labor to handle food waste: 10 USD/month [16]

- Conditions of calculation: Time it takes to put out food waste using elevators in apartments: 7.8 min/frequency, time it takes to put out food waste using FWDMs and elevators: $4 \mathrm{~min} /$ frequency, time it takes to discharge grinded food waste to the public sewage system using FWDs: 2 min/frequency.

- The labor value per ton of food waste when it is generally handled: 633 USD (= $10 \mathrm{USD} / \mathrm{month} \div 0.0158$ ton/household/month).

- The labor value per ton of food waste when it is handled after using FWDMs: 325 USD (= 633 USD/ton $\div 7.8$ min/frequency $\times 4 \mathrm{~min}$ /frequency).

Social • The labor value per ton of food waste when it is handled after using FWDs: 162 USD (= 633 USD/ton $\div 7.8 \mathrm{~min} /$ frequency $\times 2 \mathrm{~min} /$ frequency).

The value of domestic labor to handle food waste: 34 USD/month [13]

- The labor value per ton of food waste when it is generally handled: 2145 USD (= 33.895 USD/month $\div 0.0158$ ton/household/month).

- The labor value per ton of food waste when it is handled after using FWDMs: 1100 USD (= 2145/ton $\div 7.8$ min/frequency $\times 4 \mathrm{~min} /$ frequency).

- The labor value per ton of food waste when it is handled after using FWDs: 550 USD (= 2145/ton $\div 7.8 \mathrm{~min} / \mathrm{frequency}$ $\times 2 \mathrm{~min} /$ frequency).

Index to calculate GHG: Diesel $1 \mathrm{~L}=7.07 \times 10^{-4}$ ton $\mathrm{CO}_{2}$ equiv., $1 \mathrm{kWh}=4.24 \times 10^{-4}$ ton $\mathrm{CO}_{2}$ equiv.

power, diesel, tap water, methane gas) for functional unit: per 1 ton of food waste; per 0.7 ton of human excrement; or per 1.7 tons of mixture.

\section{Results and Discussion}

\subsection{The Environmental Analysis}

Figure 2 shows GHG emissions and net energy consumption from 1 ton of household organic waste according to various scenarios. In Scenario 4 (125 $\mathrm{kg} \mathrm{CO}_{2}$ equiv./ton-household organic waste), the grinded food waste discharge to the public WWTP (Human excrement was sent to the existing septic tank) was the best practice. There were increasing emission of GHG in the following order: Scenario 1 (Compositing, 133), Scenario 2 (AVWC system + Compositing, 215), Scenario 5 (FWDs + Pretreatment + Public WWTP, 298), Scenario 6 (FWDs + Biogasification + Public WWTP, 351), and Scenario 3 (FWDM + Compositing, 886). 
The evaluation of net energy consumption identified that energy consumption of Scenario 4 was the smallest at $36 \mathrm{kWh} /$ ton-waste. The order of energy consumption was as follows: Scenario 1 (125), Scenario 2 (320), Scenario 6 (445), Scenario 5 (470), and Scenario 3 (2105).

In Scenario 6, GHG emissions were $351 \mathrm{~kg} \mathrm{CO}_{2}$ equiv./ton-household organic waste in the transfer and treatment processes. However, $167 \mathrm{~kg}$ of $\mathrm{CO}_{2}$ equiv.ton-household organic waste was actually generated if the fact that the avoided impact (or saved effect, the LNG alternative effect) of methane gas recovery of $184 \mathrm{~kg}$ of $\mathrm{CO}_{2}$ equiv./ton-household organic waste was considered.

\subsection{The Economic Analysis}

Figure 3 shows the cost analysis. Scenario 1 (101 USD/ton-household organic waste) was the best, followed by Scenario 3 (221), Scenario 4 (245), Scenario 5 (450), Scenario 2 (558), and Scenario 6 (592). If the cost of 17 USD/ton-waste by using biogas in the private power station was applied, the net cost was 575 USD/ton-waste.

However, the result, which analyzed the social cost by reflecting the value of domestic labor about handling and separating food waste for collection of $10 \mathrm{USD} /$ month, has found that the cost of Scenario 4 (343 USD/tonhousehold organic waste) was most efficient followed by Scenario 3 (416), Scenario 1 (481), Scenario 5 (547), Scenario 6 (689; net cost 672), Scenario 2 (938), in order.

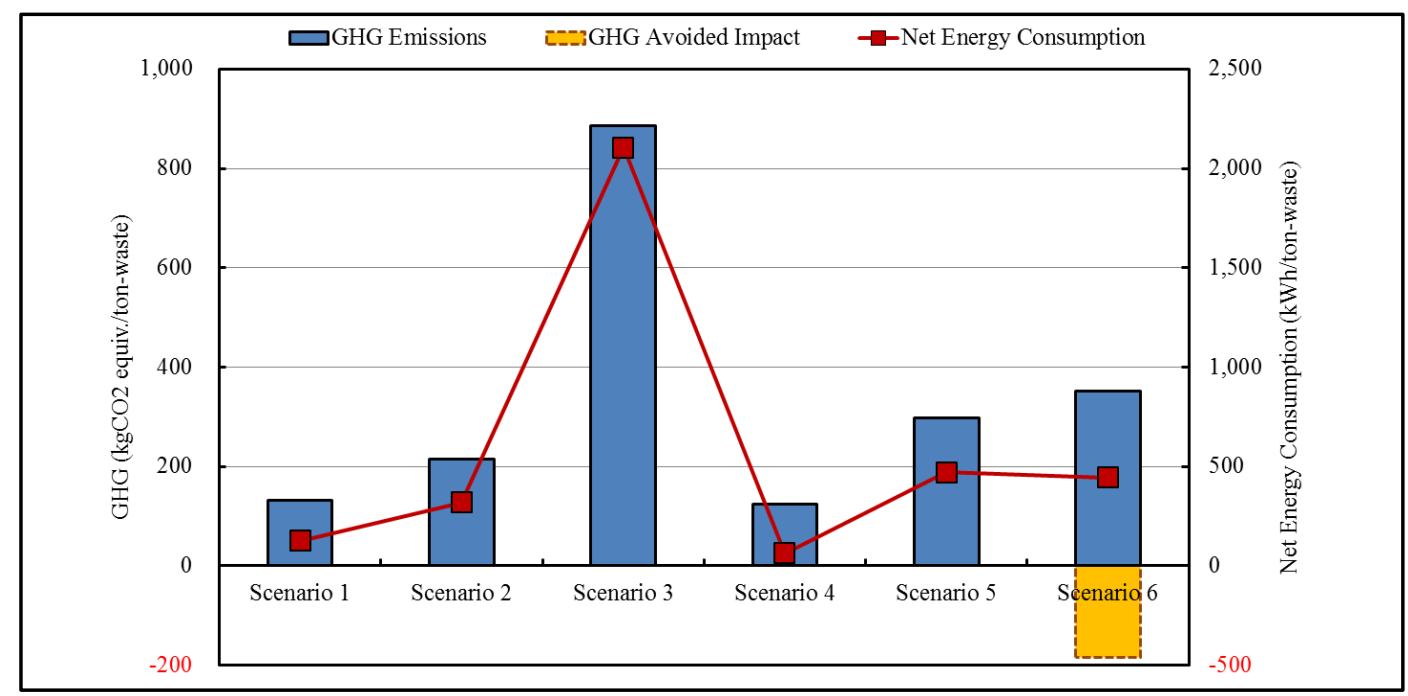

Figure 2. GHG emissions and net energy consumption in various scenarios.

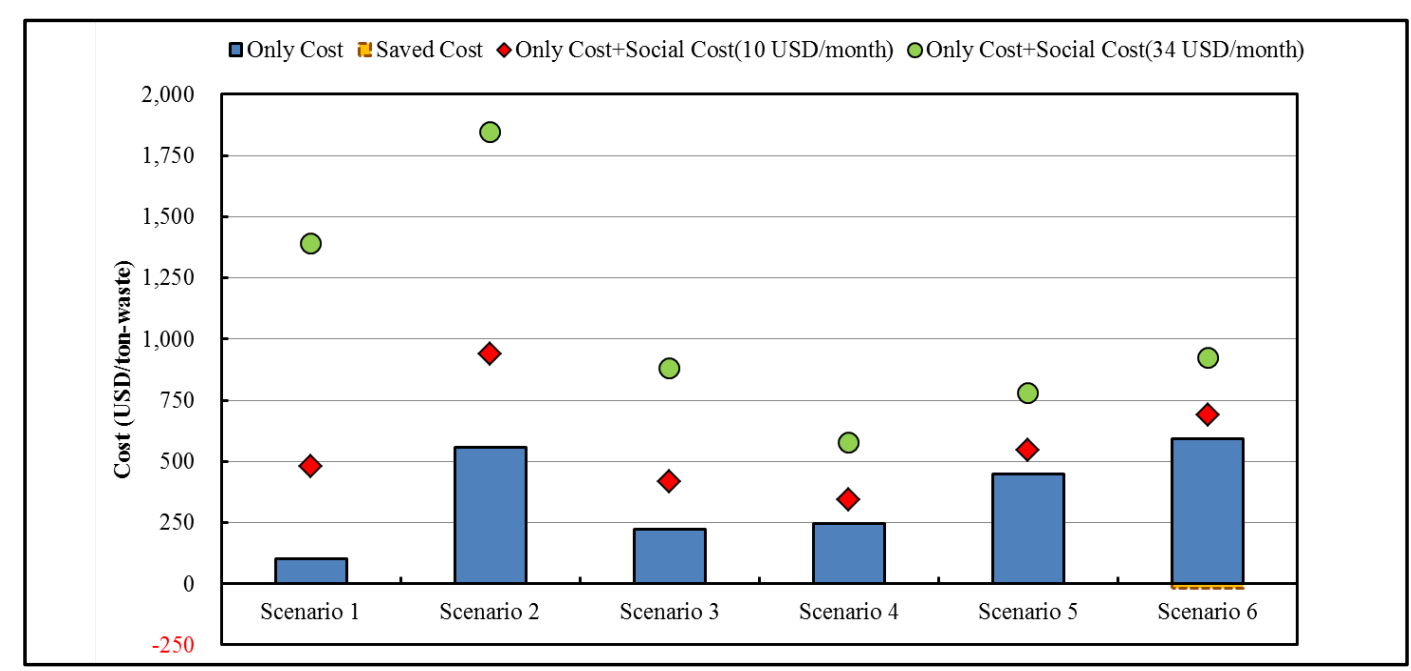

Figure 3. Cost analysis in various scenarios. 
By considering domestic labor of 34 USD/month, the cost of Scenario 4 (575 USD/ton-household organic waste) was the most efficient followed by Scenario 5 (779), Scenario 3 (881), Scenario 6 (922; net cost 905), Scenario 1 (1388), and Scenario 2 (1845) in order.

\section{Conclusions}

In the environmental aspect, the scenarios including only compositing and only FWDs have been proved to be superior. The utilization of biogas in the private power station after the FWDs and domestic sewage pretreatment in the apartments was better in the GHG emissions and energy consumption than the discharge to the public WWTP after the FWDs and domestic sewage pretreatment in the apartments.

The scenario including only composting was superior to the other scenarios in the economic aspect. In considering the only transfer and treatment processes, the study discovered that the method to put out food waste by using elevators was less expensive, yet, it incurred higher social cost on handling and separating food wastes; thus, it was more efficient to use FWDs. Furthermore, the energy saving effect due to recovery of biogas has found to be larger in the environment aspect than in the economic aspect.

\section{Acknowledgements}

This project was supported by the Seoul Metropolitan Government, Republic of Korea.

\section{References}

[1] Bernstad, A. and La Cour Jansen, J. (2012)Separate Collection of Household Food Waste for Anaerobic DegradationComparison of Different Techniques from a Systems Perspective. Waste Management, 32, 806-815. http://dx.doi.org/10.1016/j.wasman.2012.01.008

[2] Lundie, S. and Peters, G.M. (2005) Life Cycle Assessment of Food Waste Management Options. Journal of Cleaner Production, 13, 275-286. http://dx.doi.org/10.1016/j.jclepro.2004.02.020

[3] Moukamnerd, C., Kawahara, H. and Katakura, Y. (2013) Feasibility Study of Ethanol Production from Food Wastes by Consolidated Continuous Solid-State Fermentation. Journal of Sustainable Bioenergy Systems, 3, 143-148. http://dx.doi.org/10.4236/jsbs.2013.32020

[4] Fuchigami, K., Mizuno, K., Minegishi, T., Atsuura, H. and Ishimoto, S. (2001) Methane Fermentation of Night Soil Sludge and Kitchen Waste Mixture. NKK Technical Review No. 85.

[5] Ministry of Environment (MOE) (2013) Annual Statistics of Waste Generation and Treatment in Korean. South Korea.

[6] Ministry of Land, Infrastructure, Transport and Tourism (MLIT), Japan (2006) Studies for Impact Assessment Using LCA.

[7] Diggelman, C. and Ham, R.K. (2003) Household Food Waste to Wastewater or to Solid Waste? That is the Question. Waste Management \& Research, 21, 501-514. http://dx.doi.org/10.1177/0734242X0302100603

[8] New York City (1997) The Impact of Food Waste Disposers in Combined Sewer Areas of New York City. Local Law, 74, 3. http://www.nyc.gov/html/dep/pdf/grinders.pdf

[9] Marashlian, N. and El-Fadel, M. (2005) The Effect of Food Waste Disposers on Municipal Waste and Wastewater Management. Waste Management \& Research, 23, 20-31. http://dx.doi.org/10.1177/0734242X05050078

[10] Thomas, P. (2011) The Effects of Food Waste Disposers on the Wastewater System: aPractical Study.Water and Environment Journal, 25, 250-256. http://dx.doi.org/10.1111/j.1747-6593.2010.00217.x

[11] Fciwem, E.T.D., Andersson, P., Wievegg, A. and Carlsson, I. (2010) Surahammar: A Case Study of the Impacts of Installing Food Waste Disposers in 50\% of Households. Water and Environment Journal, 24, 309-319. http://dx.doi.org/10.1111/j.1747-6593.2010.00238.x

[12] Seoul Metropolitan Government (SMG) (2010) Pilot Project of Food Waste Disposers.

[13] Seoul Metropolitan Government (SMG) (2009) Pilot Project of Food Waste Disposers [in Korean].

[14] Evans, T.D. (2012) Domestic Food Waste-The Carbon and Financial Costs of the Options. Proceedings of the Institutions of Civil Engineer: Municipal Engineer, 165, 3-10. http://dx.doi.org/10.1680/muen.2012.165.1.3

[15] Kim, M.H., Song, Y.E., Song, H.B., Kim, J.W. and Hwang, S.J. (2011) Evaluation of Food Waste Disposal Options by LCC Analysis Form the Perspective of Global Warming: Jungnang Case, South Korea. Waste Management, 6, 2011-2120.

[16] Ministry of Environment (MOE) (2009) Introduction of Food Waste Disposer Systems. Sejong City. 
[17] National Institute of Environmental Research (NIER) (2007) The Third Korea Waste Statistical Survey. Incheon.

[18] Seoul Metropolitan Government (SMG) (2009) Plan to Improve Food Waste Treatment: The Introduction of a Food Waste Disposer. Seoul. [in Korean]

[19] Seoul Metropolitan Government (SMG) (2009) Basic Plan of Sewage Maintenance. Seoul. [in Korean]

[20] Seoul Metropolitan Government (SMG) (2009) The Analytical Result of the Water Reuse Center. Seoul. [in Korean]

[21] US EPA (2002) Onsite Wastewater Treatment Systems Manual. United States Environmental Protection Agency, Washington DC.

[22] Fuchigami, K., Mizuno, K., Minegish, T., Atsuura, H. and Ishimoto, S. (2001) Methane Fermentation of Night Soil Sludge and Kitchen Waste Mixture. NKK Technical Review, 85, 44-50.

[23] Seoul Metropolitan Government (SMG) (2011) Technological Development of Bioenergy Utilizing Food Waste and Human Excrement in Apartment Houses. Seoul.

[24] US EPA (2002) Onsite Wastewater Treatment Systems Manual. United States Environmental Protection Agency, Washington DC.

[25] US EPA (1992) Water Treatment/Disposal for Small Communities. <EPA/625/R-92/005>, United States Environmental Protection Agency, Washington DC.

[26] Ko, D.J., Kim, M.H., Park, Y.H., Son, B.Y. and Lee, J.J. (2003) The Study on Collection of Energy According to Anaerobic Lower Temperature Digestion of Food Waste. Autumn Conference Collection Korea Society of Waste Management, Jeju, 6-8 November 2003, 330-333.

[27] Park, J.S., Cha, D.W. and Seo, S.S. (2009) An Overview of Food Waste Treatment Methods in Korea. Summer Conference Collection SAREK, Gangwon-do, 24 June 2009, 427-432.

[28] Gangbuk-Gu, South Korea (2010) The Study on Cleaning Administration of Gangbuk-Gu for Efficient Management of Cleaning Business. Gangbuk-Gu, South Korea.

[29] Seoul Metropolitan Government (SMG) (2009) The Study on the Plan to Improve Treatment of Food Waste. Seoul. [in Korean]

[30] Incheon Development Institute (IDI) (2007) Status of Automated Waste Collection System and Scheme of Management Hereafter. Incheon City.

[31] Sudokwon Landfill Site Management Corporation (SLC) (2005) The Study on Enactment of the Standards to Calculate Collect, Transport, and Treat Food Waste. Seoul. [in Korean] 